\title{
Land tenure and water rights in Thailand and Vietnam - challenges for ethnic minorities in mountainous forest regions
}

\author{
Andreas Neef, Jörg Hager, Chiang Mai, Thomas Wirth, \\ Rainer Schwarzmeier, Franz Heidhues, Stuttgart
}

\section{Land, forest and water policies in comparative perspective}

For decades, government policies have adopted topdown approaches towards ethnic minorities living in the erosion-prone and ecologically fragile highlands of northern Thailand. Minority groups have long been regarded as a threat to national security and natural resources due to their uncontrollable mobility across borders, their previously extensive opium poppy cultivation and «unsustainable cultivation practices», like shifting cultivation (COLCHESTER 1995). Hence, various policy measures aimed at forcing these groups to abandon migratory livelihood practices and to switch from slash and burn to permanent cultivation. These policies went along with the demarcation of national parks, wildlife sanctuaries, watershed conservation zones and other protected areas. As a consequence, many ethnic minority farmers live under insecure property rights without legal basis on their land and are threatened by expulsion from protected areas (GANJANAPAN 2003; JOHNSON \& FORSYTH 2002; NEEF et al. 2003; VANDERGEEST 1996).

In contrast to the persistent state paradigm in northern Thailand, recent land and forest policies in northern Vietnam have aimed at a large-scale devolution of the use, management and governance of land and forest (Table 1), reversing the collectivization process which had started after independence from the French colonizers in 1954 and had been expanded to the South after reunification in 1975. Since the mid-1990s, land use rights have been allocated to farm households under the Land Law of 1993, providing long-term tenure security for farmers. The concomitantly issued so-called red book certificates (RBC) guarantee the rights to exchange, transfer, inherit, mortgage, and lease land use rights. This dramatic reform of land tenure followed a cautious decollectivization process which started in the early 1980s. In comparison to tenure reform of the agricultural sector, changes in forest tenure were initiated later. Both the Law on Protection and Development of Forests enacted in 1991 and Decree 327 referring to «Regreening of the barren hills» issued in 1993 did not have a major impact on forest conservation, due to lack of participation by local people, diversion of funds for other purposes, and poor planning (SIKOR 1998). In
1998, the so-called 5 million ha program was initiated, with the ambitious target of establishing 2 million ha of protected forest and 3 million ha of production forest between 1998-2010 (WirTH et al. 2004). This program identifies rural households as the key actors in the restoration of barren land and protection of forests, while neglecting communal forms of forest management, which has had a long-standing tradition since pre-colonial times in Vietnam.

Whereas land and forest tenure policies show marked differences between Thailand and Vietnam, both countries have adopted similar approaches to water policy and water management. Decentralized water management and small-scale irrigation development through river basin and sub-basin committees is high on both countries' agenda. In Thailand, first pilot sites have been established in three regions to test the effectiveness of stakeholder participation in managing the country's water resources. While until the late 1990 s, the management of water resources was characterized by institutional and legal pluralism and lack of coordination between various agencies involved in water governance (cf. MingSARn et al. 2001), a more comprehensive Water Resources Bill - based on consultations with grassroots groups and local people in Thailand's 25 river basins - was drafted in 2004 and is currently undergoing a series of public hearings before its expected promulgation in 2006 (SAMABUDDHI 2004). In Vietnam, a new Law on Water Resources was promulgated in 1999, which acknowledges that organizations and individuals have the right to exploit and use water resources for sustaining agricultural production and people's livelihoods (Le THAC CAN et al. 2001). Not surprisingly for a socialist country, however, state authorities and formal administrative structures continue to play an important role in the decision-making processes related to water governance.

In this paper, the implications of the respective resource policies for resource management in mountain forest regions are discussed. Following this introduction is a desription of the methods implemented during field research (section 2). In section 3, case studies from the two countries are presented, selected for their illuminative insight into the particular challenges and conflicts that ethnic minority groups are currently facing as regards resource entitlements and how these affect their livelihoods and the protection and use of natural resources. Section 4 puts the cases in a comparative perspective and presents the main conclusions drawn. 


\begin{tabular}{|c|c|c|}
\hline & Mountains of northern Thailand & Mountains of northern Vietnam \\
\hline Land policy & $\begin{array}{l}\text { Ambiguous land policy, no land titles } \\
\text { issued in protected areas, but toleration of } \\
\text { settlements and agricultural activities }\end{array}$ & $\begin{array}{l}\text { Comprehensive land law, allocation of land } \\
\text { use certificates in mountainous areas with the } \\
\text { exception of a few protected areas }\end{array}$ \\
\hline Forest policy & $\begin{array}{l}\text { State-paradigm of forest protection and } \\
\text { management, no legal basis for community } \\
\text { forestry, community forestry bill on hold } \\
\text { due to conflicts over the role of community } \\
\text { forestry in protected areas }\end{array}$ & $\begin{array}{l}\text { Emphasis on individual households for } \\
\text { reforestation and forest protection, no specific } \\
\text { community forestry law, latest legal changes } \\
\text { introduced the possibility to assign forest land } \\
\text { with long-term contracts to groups and other } \\
\text { collective legal entities }\end{array}$ \\
\hline Water policy & $\begin{array}{l}\text { Decentralization efforts, but lack of } \\
\text { coordination between state agencies and } \\
\text { complexity of legal system, establishment } \\
\text { of river basin committees in a pilot stage }\end{array}$ & $\begin{array}{l}\text { Decentralization of water management, } \\
\text { general water law, de facto acknowledgement } \\
\text { of stakeholder participation in form of } \\
\text { communal water user groups }\end{array}$ \\
\hline Major actors & $\begin{array}{l}\text { Royal Forest Department, Royal Project } \\
\text { Foundation, upstream ethnic minority } \\
\text { villages (e.g. Hmong, Lahu), downstream } \\
\text { Thai villages, external investors, private } \\
\text { companies in the agricultural sector }\end{array}$ & $\begin{array}{l}\text { Local authorities at provincial, district and } \\
\text { commune level, officials at the village level } \\
\text { (e.g. headman, party secretary), Land } \\
\text { Administration Office, ethnic minority } \\
\text { villages in upstream (e.g. Hmong, K'mu) and } \\
\text { downstream areas (e.g. Black Thai), migrant } \\
\text { Kinh }\end{array}$ \\
\hline
\end{tabular}

Tab. 1: Comparison of land tenure, forestry and water policies and major actors in resource governance in northern Thailand and northern Vietnam

Vergleich der Land-, Forst- und Wasserpolitik sowie Hauptakteure der Ressourcenregelung in Nordthailand und Nordvietnam

Comparaison des politiques relatives au foncier, aux forêts et à l'eau et principaux acteurs actifs dans la gestion des ressources au nord de la Thaïlande et du Viêtnam

\section{Methodology}

In this study, open and semi-structured interviews with key persons and focus groups were conducted to collect data at different administrative and hierarchical levels. Additionally, selected Participatory Rural Appraisal (PRA) tools, such as resource mapping and transect walks, were used in several interview sessions. Quantitative data were collected by standardized questionnaires in household and village surveys to get information about tenure issues at farm household level, demographic and socio-economic factors and land use patterns.

In addition, field observations and participant observation of meetings were part of the methodological portfolio. Key event and historical analysis provided a time dimension which was of importance to understand and identify dynamics and factors of tenure changes. Secondary data were collected at the provincial, district and communal level for Vietnam and at the sub-district level for Thailand.
For the analysis of the complexity of tenure systems, the interplay and strategies of various actors to gain control over resources and the impact on resource management use was made of a combination of actororiented sociology (e.g. LoNG 2001) and legal pluralism (e.g. Von Benda-Beckmann 1984; Woodman 1998).

3 Pressure on tenure regimes of highland people, resource conflicts and local coping strategies: case studies from Northwest Vietnam and North Thailand

\subsection{Yen Chau district, Son La province, Northwest Vietnam}

\subsubsection{Description of the study area and main actors in} the land allocation process

Yen Chau district of Son La province is situated along the national road no. 6 at the border to Laos, $250 \mathrm{~km}$ from the capital Hanoi (Figure 1). Its economy is based on agriculture with rice production for subsistence and maize, fruit trees and animal husbandry for cash 


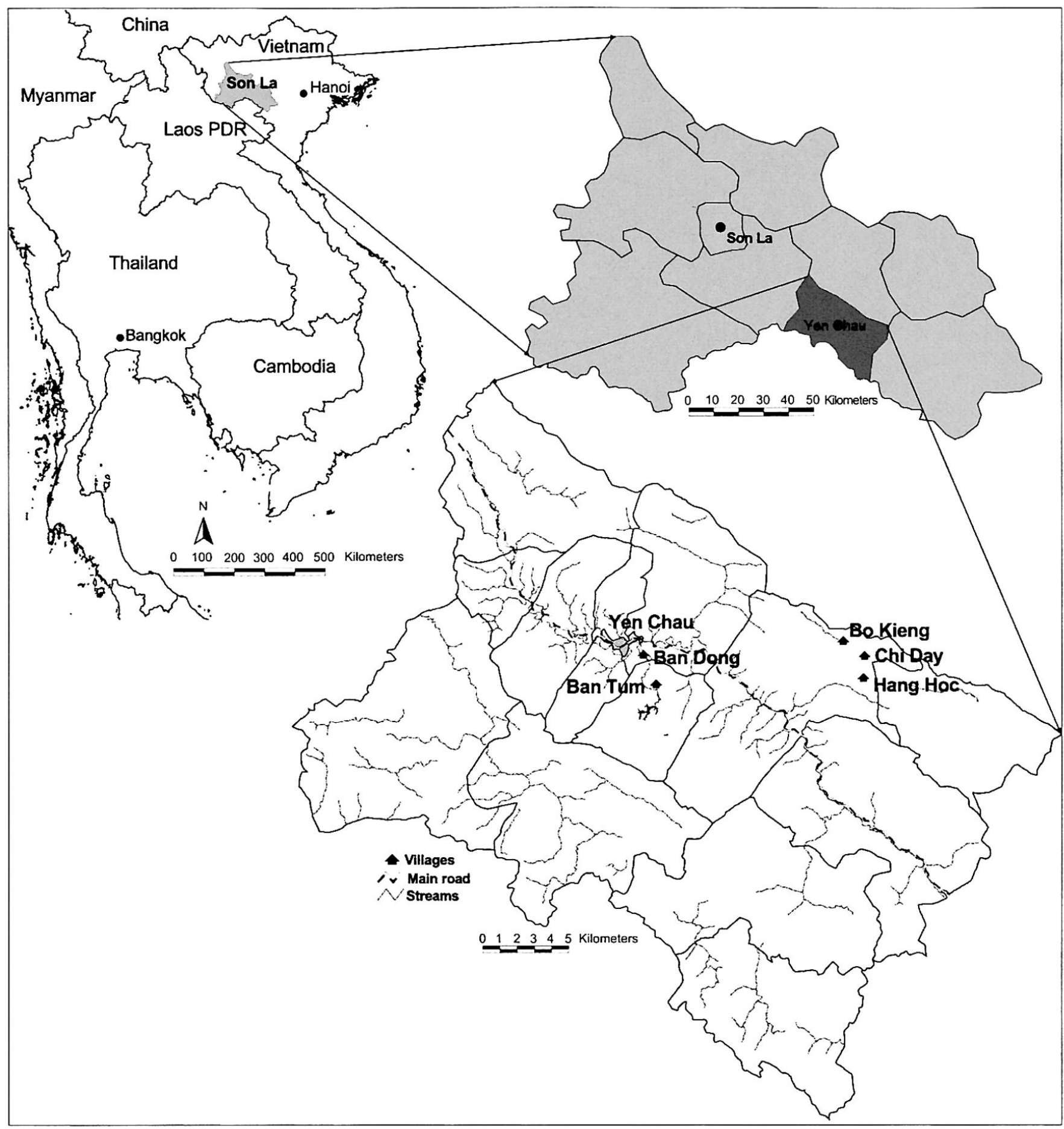

Fig. 1: Research area Yen Chau district in northern Vietnam Untersuchungsgebiet Yen Chau Distrikt in Nordvietnam Zone d'étude du district de Yen Chau dans le nord du Viêtnam

Source: ESRI-world data, General Department of Land Administration of the Socialist Republic of VietNAM; cartography: P. ELSTNER

income generation. The altitude of Yen Chau varies from $200 \mathrm{~m}$ to $1420 \mathrm{~m}$ above sea level. The total area of Yen Chau is 84,000 ha of which around 14,000 ha was declared agricultural land in the year 2000 . The popula- tion in 2005 was 63,191 persons in 13,597 households from 12 ethnic groups. The population is dominated by the Black Thai $(53.5 \%)$, followed by Kinh or ethnic Vietnamese $(21.1 \%)$, Hmong (12.8\%), Xinh Mun 
(11.9\%) and Kho-mu (0.4\%). According to information obtained from the local authorities, the population of Yen Chau more than doubled in the past 20 years.

The farmers of ethnic minority communities (Black Thai, Hmong) and Kinh migrants, resettled from the densely populated river deltas, were the main target groups of the land allocation process which started in 1994. However, they were not just passive recipients of the so-called red book certificates (RBC) but also main actors as they had to apply for their land rights. Black Thai communities, in particular, are highly diverse in terms of power, access to information, and wealth. The Black Thai villages are organized in clans, with one dominant clan occupying the important positions within the village and its organizations. The village units of the mass organizations, such as Farmers' Union and Women Union, and the Communist Party were important means to gain information on the preparation of the land allocation process. At district level, representatives of these organizations were also involved in the negotiation process. A strong influence on the implementation of the land allocation process in the village was exerted by the village security council, which is linked to the District police. Among other tasks, these councils are responsible for the solution of land conflicts. Often sons of important families are members in this council and the village headman or an older member of the council, the leader, takes the decisions in land disputes.

At the administrative level, the People's Committee (PC) of the District was the most important actor, being responsible for the whole process and, finally, for the approval of the RBCs. The PC was supported by the steering committee composed by representatives of the mass organizations. The Land Administration Department was responsible for the technical side of the land allocation process, like measuring and registering the plots (WIRTH et al. 2004).

\subsubsection{The gap between planning and reality: agricultural and forest land allocation}

In Yen Chau, the agricultural land allocation process following procedures set in the 1993 Land Law was first carried out in the communes along the national road no. 6 between May and July 1994, but with unsatisfactory results due to inaccurate estimates of plot sizes (Social Forestry Development Project Song DA (SFDP) 1997) and the institutional pluralism described above. Additionally, paddy land had been excluded from the land allocation by a general agreement within the district (SFDP 1997; SIKOR \& DAO Minh Truong 2000). This practice was in accordance with the tradition of the Black Thai, though not compatible with national policy. The result was a dichotomy of customary land tenure and the official cadastral system (WIRTH et al. 2004). As a consequence, the land allocation process was revised in 1999. This second land allocation strengthened the government's control over the land resources, an important goal of the process. The traditional system of regular reallocation of irrigated land officially disappeared and with it an important means of ensuring food security for the poorer households.

Prior to the land allocation process, land use plans were established at both village and commune levels in order to enhance governmental control over land use. The basis for the land use planning were land use maps from the year 2000 as well as guidelines and laws concerning land use from national and provincial authorities. The main purpose of the planning process was the delimitation of forestland based on criteria like the steepness of slopes or location.

Table 2 shows the changes in agricultural land for different classes of inclination in the Sap Vat Commune. For the year 2000, both agricultural land and «unused» land are considered to be agricultural land, as the local population also uses the latter for crop cultivation. For

\begin{tabular}{|lccccc|}
\hline Steepness of the slope [degrees] & $0-10$ & $10-25$ & $25-35$ & $>35$ & Total \\
\hline Land use map 2000 & 545 ha & 1040 ha & 587 ha & 240 ha & 2412 ha \\
Land use planning 2010 & 483 ha & 638 ha & 292 ha & 91 ha & 1504 ha \\
\hline Changes in \% & -11 & -39 & -50 & -62 & -38 \\
\hline
\end{tabular}

Tab. 2: Planned changes for agricultural land in the Community Sap Vat

Geplante Änderungen für Ackerland in der Gemeinde Sap Vat

Changements agricoles planifiés dans la commune de Sap Vat

Source: Geographical information systems (GIS)-analysis of the land use planning based on a $10 \mathrm{~m}$ digial elevation model (DEM) of the commune 


\begin{tabular}{|lcccccccccc|}
\hline & \multicolumn{2}{c}{1970} & \multicolumn{2}{c}{1980} & \multicolumn{2}{c}{1990} & \multicolumn{2}{c|}{$\mathbf{2 0 0 0}$} & \multicolumn{2}{c|}{$\mathbf{2 0 0 4}$} \\
Villages & GL & FP & GL & FP & GL & FP & GL & FP & GL & FP \\
\hline Ban Tum (Black Thai) & 13 & 5.8 & 15 & 6.3 & 8 & 7.2 & 0 & 10.5 & 0 & 10.5 \\
Ban Dong (Black Thai) & 23 & 0.3 & 23 & 0.5 & 15 & 1.0 & 0 & 2.7 & 0 & 2.7 \\
Bo Kieng (Hmong) & 25 & 0 & 25 & 0 & 19 & 0 & 10 & 0 & 10 & 0 \\
Hang Hoc (Hmong) & 0 & 0 & 15 & 0 & 5 & 0 & 5 & 0.1 & 2 & 0.63 \\
Chi Day (Hmong) & 14 & n.a. & 16 & n.a. & 14 & n.a. & 8 & n.a. & 8 & n.a. \\
\hline
\end{tabular}

Tab. 3: Development of grazing land (GL) and fish ponds (FP) areas in the investigated villages (1970-2004) in ha Räumliche Ausdehnung des Weidelandes und der Fischteiche in den untersuchten Dörfern (1970-2004) in Hektaren

Augmentation de la surface consacrée aux terres pâturées $(G L)$ et aux étangs piscicoles $(F P)$ dans les villages d'étude (1970-2004) en ha

Source: Agricultural Department Yen Chau district, 2005

the year 2010, the categories agricultural land, grazing land and vegetables were subsumed under the term agricultural land. Due to the poor mapping quality, especially of the land use planning map, the exact figures might be somewhat different in reality. Nevertheless, Table 2 shows clearly that the availability of agricultural land is expected to decrease to a greater extent on steeper slopes than on gentle slopes. Still, substantial areas of steep slopes will remain under agricultural use.

The gap between planning and reality is particularly evident in the reforestation efforts of the district. Officially, the forest cover has increased substantially as a result of the 327 Program and its successor, the 5 Mio. ha Program (Dao No). In Yen Chau district, some 541 ha in 48 villages were reforested according to official figures. However, large parts of the land allocated for reforestation has actually been put under agricultural use, given the much higher short-term benefits of cash crop production. Moreover, since the Dao No Program entailed the allocation of underutilized communal land to individual households, village officials have often used their social position to take the lion's share and to exclude villagers without close connections to local authorities and state agencies from the allocation process (cf. NeEF \& SChWARZMEIER 2001).

\subsubsection{Impact of the land allocation process on communal pastures}

The changes in natural resource tenure and management policies, including allocation of individualized land use rights as the final step in agricultural reforms, diminished the potential of previously communitybased grazing land management. In almost all villages in the study area, common grazing land has existed for generations. Prior to the collectivization process, common grazing land was one part of the traditional land use system for both Thai and Hmong communities. These pastures were composed of fallow and forest land with communal management coordinating collective activities, such as yearly fencing and looking after the animals on a rotational basis. During the time of the agricultural cooperatives in the 1970s and 1980s, pasture land and ruminants belonged to the cooperatives and were managed by the management board of the cooperatives. Today, grazing land has been considerably reduced in some villages and completely abandoned in others. According to the Department of Agriculture and Rural Development of Son La province, grazing land in the province has decreased from about 44,000 ha in the 1970 s to only about 2,000 ha in 2004. Hence, the tenure niche for communal grazing land management has been undermined by recent land tenure changes, land use rights for communities being formally non-existent.

In the research area, only Hmong settlements in highland areas comprising relatively extensive agricultural and forest areas have enough land resources to retain communally used pastures to a limited extent. These are usually not sufficient to provide enough forage for ruminants throughout the year. In the investigated Black Thai villages, pastures and potential grazing areas disappeared (Table 3 ) and households now depend on individual grazing activities around the residential area, the village and riparian areas.

Hence, further expansion of ruminant production in Yen Chau district, which has been one of the pillars of its rural economy for several decades, appears impossible. 


\subsubsection{The impact of the land allocation process on long-term investments}

Farmers in Yen Chau district have intensified their production systems considerably since the start of the decollectivization process (NeEF \& SchwarzMEIER 2001). As the land allocation process created a dichotomy between the formal and the customary land tenure regime, tenure security could be obtained from either system, a phenomenon which has been described as "forum shopping" in the literature on legal pluralism (Meinzen-Dick \& Pradhan 2002; Von BendaBECKMANN 1984). In the Black Thai villages along the national road no. 6 , where all suitable land was already covered with paddy rice terraces when the land allocation process started, farmers have recently begun to diversify their production system by planting fruit trees. Another important long-term investment that has become more prominent in recent years is aquaculture in fish ponds in or close to the residential area. Particularly in the Black Thai villages that have a longstanding tradition in small-scale aquaculture, the area of fish ponds has been expanded (Table 3 above).

Obvious tradeoffs exist, however, between these investments and the intensification of the cropping system. The increased use of agrochemicals in paddy fields that are hydrologically linked with the fish ponds seriously jeopardize the future of aquaculture in the area. Most investments (terracing of new paddy fields, fruit trees, aquaculture) are also likely to increase the extraction of once abundant water resources which could induce future water shortages during the dry season.

Whether these trends of diversification and intensification will be able to sustain a growing population without the creation of non-farm opportunities remains doubtful. The construction of a huge hydroelectric dam in Son La province, which started in 2005, will further increase the pressure on scarce land resources.

\subsection{Mae Sa watershed, Chiang Mai province, northern Thailand}

\subsubsection{Description of the study area}

The Mae Sa watershed covers an area of $142.2 \mathrm{~km}^{2}$ and extends from 20 to $45 \mathrm{~km}^{2}$ northwest of Chiang Mai. The watershed is intensively used for market-oriented agriculture, mainly fruit, flower and vegetable production. The Mae Sa river feeds into the Ping river, one of the main tributaries of the Chao Phraya river, whose delta constitutes Thailand's «rice bowl». Major parts of the watershed are included in the Suthep-Pui National Park. The watershed is an upland area with mountainous terrain and altitudes ranging from 300 to 1400 meters above sea level. The upper part of the watershed chosen as the study area, covers the sub-district Pong Yang and is inhabited by 15,426 people with 52 percent belonging to the ethnic minority group of the Hmong and 48 percent being northern Thai (Pong YANG SubDistrict Administration (PYSA) 2002) (Figure 2).

\subsubsection{Impact of government interventions on land and forest tenure and local responses to tenure insecurity}

Mae Sa Mai is one of the largest Hmong settlements in northern Thailand, with a total population of 1765 inhabitants. Local government officials did not pay much attention to them until the year 1969 when the King paid a visit to Mae Sa Mai. He granted Thai citizenship to all villagers who made a commitment to stay permanently in their present location (LEEPREECHA 2001). Intervention from the Royal Forest Department (RFD) in Mae Sa Mai began in 1977 with the planting of 480 ha of pine and eucalyptus trees. The establishment of the Suthep-Pui National Park in 1981, which included all the residential and cultivated areas in Mae Sa Mai, dramatically changed the lives of its inhabitants. The same year, the King paid another visit to the village and - at the request of the villagers - allocated an area of about 400 ha to them for agriculture. In addition, he established a Royal Project Station (see below) for the demonstration and introduction of cash crops (LEEPREECHA 2001). While the intervention of the King provided the villagers of Mae Sa Mai with a certain level of tenure security, land claims by the Royal Forest Department (RFD) for reforestation purposes remained a permanent threat. Peach orchards in the upper part of the catchment were destroyed by RFD staff in 1982 and some villagers were arrested for encroaching on the head watersheds. In 1986, the area of Mae Sa Mai was classified as "watershed conservation area class A1», meaning that agricultural activities were officially declared illegal according to two cabinet resolutions dated May 1985 and October 1986.

Faced with continuous threats of eviction and land claims by government agencies, villagers in Mae Sa Mai, and in some of the neighboring communities, have adopted a range of strategies to enhance tenure security. Planting of fruit trees has increased tenure security in sloping areas. The National Park authorities have acknowledged these practices as being at least more sustainable than growing vegetables and other annual crops. In cases where only annual crops can be grown, permanent cultivation of the fields is a viable strategy against land claims, since extended fallow periods would ultimately lead to eviction from the land (cf. KNüPFER 1999). Buying paddy fields in the lowlands is another strategy adopted by Hmong villagers. In addition to ensuring their food self-sufficiency in rice, farmers also regard this measure as a «last retreat» in case of eviction from their land. 


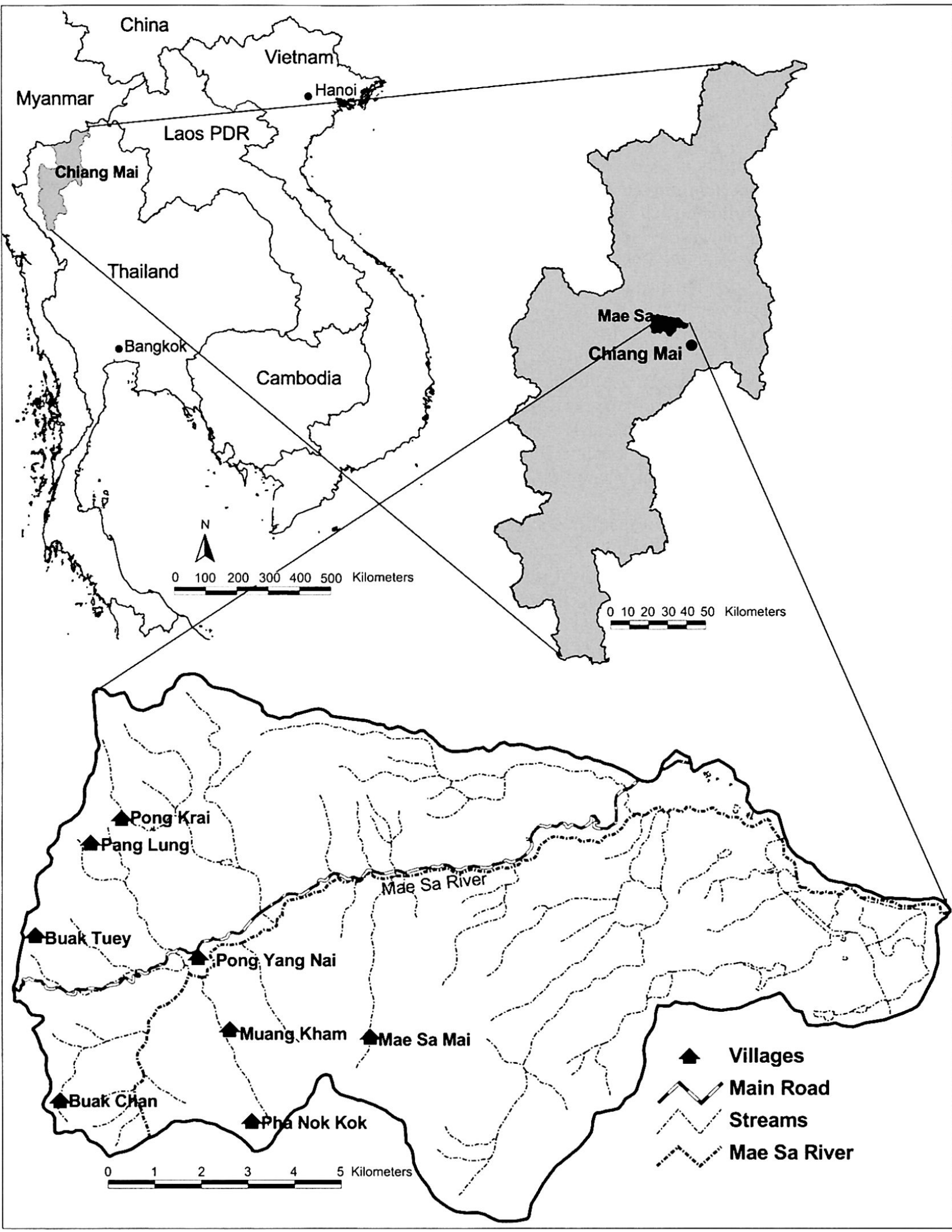

Fig. 2: Research area Mae Sa watershed in northern Thailand Das untersuchte Mae Sa-Einzugsgebiet in Nordthailand

La zone d'étude du bassin versant de Mae Sa dans le nord de la Thaïlande

Source: ESRI-world data, Royal Thai Survey DeParTment; cartography: P. Elstner 


\begin{tabular}{|lcccc|}
\hline & \multicolumn{2}{c}{ Pha Nok Kok } & \multicolumn{2}{c|}{ Muang Kham } \\
Type of customary rights & $\%$ & No. of fields & $\%$ & No. of fields \\
\hline The farmer is the owner of the field. & 80.4 & 109 & 83.6 & 56 \\
The farmer is free to grow perennial crops. & 81.5 & 110 & 94.0 & 63 \\
\hline Type of officially recognized rights & $\%$ & No. of fields & $\%$ & No. of fields \\
\hline $\begin{array}{l}\text { The farmer has an official ownership title or } \\
\text { land use certificate. }\end{array}$ & 20.0 & 27 & 76.1 & 51 \\
$\begin{array}{l}\text { The land can be used as collateral for } \\
\text { obtaining a loan. }\end{array}$ & 6.7 & 9 & 62.7 & 42 \\
\hline
\end{tabular}

Tab. 4: Types of traditional and officially recognized rights in Pha Nok Kok and Muang Kham (according to respondents' perceptions, sample of 40 farm households, 2002)

Typen von Gewohnheits- und offiziellen Rechten in Pha Nok Kok und Muang Kham (gemäss Wahrnehmung der Befragten in 40 Haushalten, 2002)

Types de droits coutumiers et officiels à Pha Nok Kok et Muang Kham (selon la perception de 40 ménages paysans en 2002)

Source: adapted from NeEF et al. 2004; data provided by P. SiRISUPLUXUNA and C. SANGKAPITUX

Apart from these individual strategies, the community and its sub-groups have also developed communal strategies to cope with insecure tenure. An old tradition of forest and tree ordination - which had been abandoned due to the influence of Christian missionaries - was revived in the mid-1980s upon the initiative of the then village headman of Mae Sa Mai. Agricultural land had to be given up to establish a protected forest area, which was done with the collective agreement of all villagers. The protected forest covering an area of about 800 ha serves as a community forest and a public demonstration of the community's willingness to conserve the forests in the head watersheds. Cooperation with government agencies is another strategy to secure the land claims of the community. In 1991 , the villagers of Mae Sa Mai reached an agreement with the National Park authorities to construct fire barriers and to monitor and extinguish forest fires in order to protect the conservation forest area. For many years, the activities of the Royal Project Station (RP) have indirectly supported the claims of the villagers of Mae Sa Mai by sustaining their livelihoods in this particular subcatchment. The continuous cooperation with the RP improves the security of their land rights and makes them less vulnerable to eviction than, for instance, their neighbors in Pha Nok Kok (see below).

\subsubsection{Upstream-downstream conflicts and resolution strategies}

As the Mae La Ngun subcatchment was not included in the 1981 boundaries of the National Park, the villages of Pha Nok Kok (Hmong) and Muang Kham (Thai), which have an upstream-downstream relationship, were not affected much by the conservation interests of the RFD until the beginning of the 1990s. In 1992, however, the area of the Suthep-Pui National Park was expanded, covering the whole village territory of Pha Nok Kok and 10 percent of the territory of Muang Kham. The expansion triggered marked disparities between the two villages in terms of tenure security as shown in the perceptions of a sample of 40 farmers during a survey in 2002 . While the differences between the perceptions of customary rights are not significant, farmers in the two villages have a significantly different tenure status under the official legal system (Table 4). From 1994 onwards, further expansion of cropping area in Pha Nok Kok was strictly forbidden by the RFD which consequently claimed at least 10 percent of the village's agricultural land.

Since the 1980s, the relationship between the two communities has been marked by conflicts over resources. particularly water. Hence, a joint committee consisting of two representatives per stream and village was set up to solve these conflicts. with a local non-governmental organization (NGO) serving as an external mediator. In the late 1990 s, one creek used by farmers of Muang Kham fell dry, leading to an acute conflict between the two villages. Joint meetings were held where the issue of water distribution was discussed and regulations were set up that would satisfy both parties, such as a standardization of the diameter of pipes. The main solution of the increasing conflicts, however, was driven by market forces: the introduc- 
tion of sweet peppers by a Dutch food company in Muang Kham brought about the construction of private wells for pumping ground water which made the farmers in this village far less reliant on surface water from upstream creeks formerly shared with farmers from Pha Nok Kok.

\subsubsection{Conflicts between local communities and external investors}

Since the 1990s, urban-based investors have started to acquire large tracts of land in the northern part of Thailand. In Mae Sa watershed, the impact of urban investors' interests and speculative activities are also being felt. In the Hmong village Buak Toey, outside investors have steadily increased their influence on the community's territory. Taking advantage of the insecure tenure situation of the villagers, some investors have cleared large tracts of forestland in protected areas - while forest authorities have turned a blind eye or rather an open hand - to grow cut flowers on a large scale and to construct a private resort. Among the investors is the kamnan, the head of the sub-district administration, which makes any legal action by the villagers against the land grabbing virtually impossible.

The land occupancy by investors goes along with an individual appropriation of water resources, as one major creek flows through the investors' land. While farmers in Buak Toey cannot afford to buy pumps and have to resort to gravity irrigation, the investors have installed a system of pumps, wells, weirs and reservoirs to secure their access to irrigation water. Thus, a once communally managed resource has been transformed into a private commodity used by wealthy landlords, with dramatic consequences for the local community. Resident farmers tap the leftovers of the water directly from the remaining creeks through pipes that are connected to storage systems in their fields.

\section{Discussion and conclusions}

Research from both case studies suggests that the implementation of national policies in land and forest have created a dichotomy between customary tenure systems and the official legal system. In the Vietnamese case, this situation of legal pluralism is reflected in a gap between the land register and the current tenure situation in the villages. This gap indicates the strong influence of customary land tenure institutions. At the same time, an individualization process has evolved, mainly caused by the allocation of both agricultural and forest land to individual households. This process has undermined communal forms of resource management, particularly evident in the case of grazing land. Results from the Vietnam case also suggest that outcomes of the land allocation process have affected social groups in the villages differently as regards their tenure security status. This is especially evident in the case of forestland allocation, where village headmen and other officials in the villages - who were supposed to be catalysts - used their central position in the process to follow their own agenda. Notwithstanding these adverse effects of the land allocation, overall tenure security has improved in the more favorable locations, reflected in enhanced long-term investments, such as terracing new paddy fields, planting of fruit trees and digging of fish ponds.

The fact that large tracts of land destined for reforestation purposes are instead put under agricultural use by the individual recipients is an expression of the need of farmers for sustaining their short-term food security. It is also expected that water in this traditionally water-rich country can become a limiting factor under a more intensified system. In these situations, communal forms of management will come under increasing strain, particularly since a legal framework for common property regimes is lacking.

Results of the case study in Thailand suggest that the dichotomy between state-governed forest land and customary property regimes in forest reserve areas evokes a variety of strategies on the part of local communities to secure their land use rights, ranging from the revival and invention of traditions to cooperation with NGOs and development projects. Most of the communal efforts focus on creating a new image of ethnic minorities as caretakers of the forest and conservers of natural resources. Hence, in a local arena characterized by political and economic pressure and widespread ignorance of local people's customary tenure arrangements, ethnic minority people have developed new forms of human agency (cf. MEINZENDick \& Pradhan 2002). The «room for manœuvre» in claiming land and forest rights in the Thai highlands depends on a complex interplay of government interests, intervention by development projects, NGOs and other actors, and the ability of local communities to influence the local administrative system in their favor. As the upstream-downstream relationship described in section 3.2.3 shows, communities are also capable of finding their own creative means to deal with intervillage resource conflicts. Where community rights are not established and protected against external interventions, however, villagers are extremely vulnerable to urban investors and speculators. This is particularly evident in well accessible locations where investments in high-value agricultural products and/or tourist facilities promise high rates of return (section 3.2.4).

The cases presented from Vietnam and Thailand provide evidence that communal forms of resource man- 
agement have come under increasing pressure. While private investments on individual agricultural land are commonplace, irrespective of whether farmers have documented land rights and a high degree of tenure security or not, common property regimes lack support from a comprehensive legal framework that protects common-pool resources, such as forests, pastures and water, from overexploitation and local communities from encroachment by outsiders and the misuse of power by village elites.

\section{Acknowledgements}

The financial support of the Deutsche Forschungsgemeinschaft (German Research Foundation) in carrying out this long-term study is gratefully acknowledged.

\section{References}

Benda-Beckmann, F. von (1984): The broken stairs to consensus. Village justice and state courts in Manangkabau. - Dordrecht: Foris.

COLCHESTER, M. (1995): Indigenous peoples' rights and sustainable resource use in South and Southeast Asia. - In: Harrison, R., Gray, A. \& B. Kingsbury (eds): Indigenous peoples of Asia. - Michigan: Association for Asian Studies: 59-76.

GANJANAPAN, A. (2003): Complexity of rights and legal pluralism in participatory watershed development in Thailand. - In: Xu JiAnCHU \& S. MieKSELl (eds): Landscapes of diversity. Indigenous knowledge, sustainable livelihoods and resource governance in Montane Mainland Southeast Asia. - Proceedings of the III Symposium on MMSEA, 25-28 August 2002, Lijiang, P.R. China. - Kunming: Yunnan Science and Technology Press: 207-212.

Johnson, C. \& T. Forsyth (2002): In the eyes of the state. Negotiating a «rights-based approach» to forest conservation in Thailand. - In: World development 30, 9: 1591-1605.

KNÜPFER, J. (1999): Bäuerliche Strategien im Spannungsfeld zwischen staatlicher Aufforstungspolitik und Einkommenssicherung in Wassereinzugsgebieten Nordthailands. - Master thesis, Institute of Agricultural Economics and Social Sciences in the Tropics and Subtropics, University of Hohenheim.

Le Thac Can, Do Hong Phan \& Le Quy An (2001): Environmental governance in Vietnam in a regional context. - In: BADENOCH, N. \& M. DupAR (eds): Mekong regional environmental governance. Perspectives on opportunities and challenges. - Papers of the REPSI Mekong Regional Environmental Governance Research and Dialogue Group, Chiang Mai, Thailand: 13-26.

LeEPREeCha, P. (2001): Kinship and identity among Hmong in Thailand. - PhD dissertation, Seattle:
Department of Anthropology, University of Washington.

LoNG, N. (2001): Development sociology. Actor perspectives. - London, New York: Routledge.

Meinzen-Dick, R.S. \& R. Pradhan (2002): Legal pluralism and dynamic property rights. - CAPRi working paper No. 22, Washington, D.C.: International Food Policy Research Institute.

MingSARN, K. et al. (2001): Policy approaches for water management in Thailand. - Bangkok: Thailand Development Research Institute.

Neef, A. \& R. Schwarzmeier (2001): Land tenure systems and rights in trees and forests. Interdependencies, dynamics and the role of development cooperation - the case of Mainland Southeast Asia. - Eschborn: German Agency of Technical Cooperation (GTZ).

Neef, A., Onchan, T. \& R. Schwarzmeier (2003): Access to natural resources in Mainland Southeast Asia and implications for sustaining rural livelihoods - the case of Thailand. - In: Quarterly journal of international agriculture 42, 3: 329-350.

Neef, A., Sirisupluxana, P., Sangkapitux, C. \& F. HeIDHuEs (2004): Tenure security, long-term investment and nature conservation - getting causalities and institutions right. - Paper presented at the $85^{\text {th }}$ Seminar of the European Association of Agricultural Economists «Agricultural development and rural poverty under globalization. Asymmetric processes and differentiated outcomes», Florence, 8-11 September 2004.

Pong Yang Subdistrict Administration (PYSA) (2002): Subdistrict development plan for 2003. - Mae Rim, Thailand: PYSA.

SAMABUDDHI, K. (2004): Row likely over water resource bill. - In: Bangkok Post, August 5: 4.

SiKOR, T. (1998): Forest policy reform. From state to household forestry. - In: Poffenberger, M. (ed.): Stewards of Vietnam's upland forests. - Berkeley: Asia Forest Network: 18-37.

Sikor, T. \& Dao Minh Truong (2000): Sticky rice, collective fields. Community-based development among the Black Thai. - Hanoi: Agricultural Publishing House.

Social Forestry Development Project Song Da (SFDP) (1997): Land allocation in the Song Da Watershed. - Paper presented at the National Workshop on Participatory Land Use Planning and Forest Land Allocation, 4-6 December 1997, Hanoi.

VANDERgeEst, P. (1996): Property rights in protected areas. Obstacles to community involvement as a solution in Thailand. - In: Environmental conservation 23, 3:259-268.

Wirth, T., Dao Chau Thu \& A. Neef (2004): Traditional land tenure among the Black Thai and its implication on the land allocation in Yen Chau district, Son La province, Northwest Vietnam. - In: Gerold, G., Fremerey, M. \& E. Guhardja (eds): Land use, nature conservation, and the stability of rainforest margins 
in Southeast Asia. - Berlin, Heidelberg, New York, London, Paris, Tokyo: Springer-Verlag: 119-134.

Woodman, G.R. (1998): Ideological combat and social observation. Recent debate about legal pluralism. - In: Journal of legal pluralism 42: 95-106.

\section{Abstract: Land tenure and water rights in Thailand and Vietnam - challenges for ethnic minorities in mountainous forest regions}

Ethnic minorities in the mountainous forest regions of northern Thailand and northern Vietnam live in a particularly restrictive political, social and economic environment. Widespread degradation of land, water and forest resources has adverse effects on the livelihoods of these groups. Given the dramatically increasing scarcity of natural resources, regulation of resource access and allocation are becoming fundamental for the development of sustainable resource management, in which an active participation of the local population in planning and implementation is a crucial prerequisite. In this article, the political and institutional framework of current resource policies and resulting conflicts are discussed for the two countries. Drawing on various case studies, typical land and water tenure conflicts are presented and their impact on the protection and use of natural resources and on the livelihoods of ethnic minorities is analyzed.

\section{Zusammenfassung; Land- und Wasserrechtsprobleme ethnischer Minderheiten in Bergwaldregionen in Thailand und Vietnam}

Ethnische Minderheiten in den Bergwaldregionen Nordthailands und Nordvietnams sind von besonders restriktiven politischen, sozialen und ökonomischen Rahmenbedingungen betroffen. Die weitreichende Degradierung der Land-, Wasser- und Waldressourcen gefährdet zunehmend die Lebensgrundlage dieser Bevölkerungsgruppen. Mit der dramatisch gestiegenen Verknappung der natürlichen Ressourcen bekommen Zugangsregelungen und Verteilungsfragen grundsätzliche Bedeutung für die Entwicklung nachhaltiger Ressourcennutzungskonzepte, in denen eine aktive Beteiligung der lokalen Bevölkerungsgruppen an der Planung und Umsetzung unabdingbare Voraussetzung ist. In diesem Beitrag werden politische und institutionelle Rahmenbedingungen der aktuellen Ressourcenpolitik in den beiden Ländern sowie daraus abgeleitete Konflikte dargestellt. An Fallbeispielen werden typische Land- und Wasserrechtskonflikte vorgestellt und deren Auswirkungen sowohl auf den Schutz und die Nutzung natürlicher Ressourcen als auch auf die Lebensbedingungen der ethnischen Minderheiten analysiert.

\section{Résumé: Les droits d'utilisation du sol et de l'eau des minorités ethniques des montagnes boisées de Thailande et du Viêtnam}

Les minorités ethniques des régions montagneuses boisées du nord de la Thaillande et du Viêtnam se trouvent dans une situation extrêmement restrictive quant à l'environnement politique, social et économique. La dégradation continue et vaste des ressources du paysage en général, de l'eau et de la forêt a des conséquences défavorables pour les conditions de vie de ces groupes. Face à la réduction dramatique des ressources naturelles, des régulations concernant l'accès et la répartition de la terre sont d'une importance fondamentale. Pour atteindre un développement soutenable, la participation de la population locale dans le cours de la planification et de la réalisation est une nécessité absolue. Le présent article traite des conditions générales de la politique actuelle dans les deux pays en ce qui concerne les ressources ainsi que des conflits provenants de cette situation.

Dr. Andreas Neef, Jörg Hager, M.A. Social Anthropology, The Uplands Program, Hohenheim Office, Faculty of Agriculture, Chiang Mai University, Chiang Mai 50200, Thailand.

e-mail: neef@uni-hohenheim.de

JoergHager@gmx.net

Dipl.-Forstwirt Thomas Wirth, SFB 564 - The Uplands Program, Schloss, Osthof-Süd, University of Hohenheim (796), D-70593 Stuttgart, Germany.

e-mail: t-wirth@gmx.ch

Dipl.-Ing. agr. Rainer Schwarzmeier, Prof. Dr. Franz Heidhues, Institute of Agricultural Economics and Social Sciences in the Tropics and Subtropics (490), Rural Development Economics and Policy, Schloss, Osthof-Süd, University of Hohenheim, D-70593 Stuttgart, Germany.

e-mail:

rschwarz@uni-hohenheim.de

heidhues@uni-hohenheim.de

\section{Manuskripteingange/received/manuscrit entré le}

14.3.2006

Annahme zum Druck/accepted for publication/accepté pour l'impression: 13.12.2006 